\title{
Wojciech Ewertowski, Tomasz Sowada
}

Uniwersytet im. Adama Mickiewicza w Poznaniu

Instytut Geografii Społeczno-Ekonomicznej i Gospodarki Przestrzennej

e-mail:wewert@amu.edu.pl; tomasz.sowada@amu.edu.pl

\section{Użytkownicy zewnętrzni polskiego miasta - wnioski z warsztatów gallery walk ${ }^{1}$}

\begin{abstract}
Zarys treści: Artykuł zawiera wyniki warsztatów gallery walk przeprowadzonych podczas seminarium podsumowującego projekt EBEH: „Przyjezdni w strukturze miasta - miasto wobec przyjezdnych, analiza struktur społeczno-przestrzennych miasta w kontekście teorii "użytkownika zewnętrznego»". Warsztaty stanowiły formę dyskusji o czterech grupach użytkowników zewnętrznych polskich miast: studentach, turystach, obcokrajowcach i mieszkańcach strefy podmiejskiej, brali w nich udział eksperci z różnych dyscyplin zajmujących się problematyką miasta. Wyniki dyskusji odniesione zostały do przyjętych założeń teorii „użytkownika zewnętrznego”. Umożliwiło to odpowiedź na pytanie, czy użytkownicy zewnętrzni odgrywają tak znaczącą rolę w kształtowaniu struktury miasta polskiego, jak jest to opisane $\mathrm{w}$ literaturze $\mathrm{w}$ przypadku miast zachodnioeuropejskich.
\end{abstract}

Słowa kluczowe: gallery walk, użytkownicy zewnętrzni, struktura miasta

\section{Wprowadzenie}

Kategoria użytkowników zewnętrznych miasta (city users) pojawia się w literaturze w pracach takich autorów, jak Martinotti (1996) i Judd (2003). Jest to jedna z czterech populacji związanych ze współczesnymi miastami (Martinotti 1996, Nuvolati 2003), przybywająca do nich z zewnątrz w celu skorzystania $z$ oferty usługowej, mająca współcześnie coraz większy wpływ na jego strukturę społeczną i przestrzenną (Martinotti 1996). W pewnych dziedzinach życia użytkownicy zewnętrzni odgrywają nawet ważniejszą rolę niż mieszkańcy, wypierając ich z niektórych obszarów i zawłaszczając je. W skrajnych przypadkach relacje pomiędzy mieszkańcami, a użytkownikami zewnętrznymi mogą przyjmować postać konfliktu, związanego z kwestiami kulturowymi lub ekonomicznymi (Nuvolati

1 Artykuł stanowi podsumowanie warsztatów zorganizowanych dzięki finansowaniu ze środków projektu NCN nr UMO-2011/03/B/HS4/01171: „Przyjezdni w strukturze miasta - miasto wobec przyjezdnych: analiza struktur społeczno-przestrzennych miasta w kontekście teorii «użytkownika zewnętrznego»". 
2003). Na kategorię użytkowników zewnętrznych składają się: turyści, studenci, obcokrajowcy na pobyt czasowy, mieszkańcy strefy podmiejskiej oraz przyjezdni biznesmeni i naukowcy.

Niniejszy artykuł przedstawia wyniki warsztatów gallery walk, które zostały przeprowadzone podczas seminarium zorganizowanego $\mathrm{w}$ dniach 15.0417.04.2015 r. w ramach projektu EBEH - „Przyjezdni w strukturze miasta miasto wobec przyjezdnych, analiza struktur społeczno-przestrzennych miasta w kontekście teorii "użytkownika zewnętrznego»". Brało w nich udział 13 specjalistów z zakresu gospodarki przestrzennej, geografii społeczno-ekonomicznej, socjologii, kulturoznawstwa oraz antropologii z różnych ośrodków akademickich Polski².

Temat mieszkańców miasta oraz użytkowników zewnętrznych i ich roli w kształtowaniu struktury miasta pojawiał się podczas całego seminarium. Przedstawione warsztaty były próbą wykorzystania wiedzy eksperckiej z różnych dziedzin w celu uzyskania, w drodze interdyscyplinarnej dyskusji, nowej wiedzy odnoszącej się do tego zagadnienia. Celem warsztatów było również poszukiwanie odpowiedzi na pytanie, czy i w jaki sposób użytkownicy zewnętrzni odgrywają tak znaczącą rolę $\mathrm{w}$ kształtowaniu struktury miasta polskiego, jak opisane jest to $\mathrm{w}$ literaturze dotyczącej miast zachodnioeuropejskich.

\section{Metodyka}

Warsztaty typu gallery walk zaliczane są do metod jakościowych wykorzystywanych w dydaktyce i mają na celu aktywizację uczniów i zachęcanie ich do pracy zespołowej oraz dzielenia się pomysłami (Kolodner 2002, Francek 2006). Polegają na przemieszczaniu się uczestników badania, podzielonych na kilkuosobowe grupy, pomiędzy kolejnymi „stacjami” (tablicami lub kartkami papieru), przy których zadawane są pytania dotyczące konkretnego tematu (Francek 2006) lub prezentowane są projekty uczniów (Fasse, Kolodner 2000, Holbrook, Kolodner 2000, Kolodner 2002). Przy każdej stacji prowadzona jest dyskusja, z której wnioski są następnie zapisywane. Uczestnicy przedstawiają nie tylko własne pomysły, ale biorą również pod uwagę efekty pracy poprzednich grup. Pobyt grup przy każdej stacji jest ograniczony czasowo, dzięki czemu żadna z nich nie wyczerpie całkowicie tematu (Francek 2006). Ostatnim etapem gallery walk jest dyskusja podsumowująca osiągnięte rezultaty.

Warsztaty będące przedmiotem niniejszego artykułu podzielone zostały na cztery części tematyczne („stacje”) odnoszące się do różnych grup użytkowników zewnętrznych miasta - cudzoziemców, studentów, mieszkańców strefy podmiejskiej oraz turystów. W ramach każdej z nich poddawano dyskusji trzy zagadnienia: miejsca kojarzące się z daną grupą, charakterystyczne dla niej zachowania

2 Prof. zw. dr hab. Rafał Drozdowski; prof. zw. dr hab. Andrzej Lisowski; prof. zw. dr hab. Ewa Rewers; prof. zw. dr hab. Tadeusz Stryjakiewicz; prof. UŁ dr hab. Iwona Jażdżewska; prof. UAM dr hab. Jacek Schmidt; dr Michał Męczyński; dr Mikołaj Madurowicz; dr Marek Nowak; dr Paulina Tobiasz-Lis; mgr Jacek Kubera; mgr Piotr Luczys; mgr Karolina Sydow. 
oraz wkład w życie miasta (zarówno pozytywny, jak i negatywny). Uczestnicy badania mogli również zgłaszać własne propozycje, nie pasujące do żadnego z podanych zagadnień. Warsztaty prowadzone były w grupach trzy- lub czteroosobowych, przechodzących cyklicznie pomiędzy stacjami.

Gallery walk przedstawiony w niniejszym artykule został zmodyfikowany $\mathrm{w}$ stosunku do metody wykorzystywanej w dydaktyce, ponieważ uczestnikami warsztatów były osoby posiadające wiedzę ekspercką. Przy stacjach znajdował się moderator, który jednak nie miał za zadanie odpowiadać na pytania dotyczące zagadnienia, jak to się dzieje w przypadku prezentacji projektów przez uczniów, ale nadzorował dyskusję uczestników oraz obserwował jej przebieg i efekty, a także dokonywał podsumowania wyników po zakończeniu warsztatów.

\section{Wyniki}

Wyniki uzyskane podczas warsztatów, przeprowadzonych w oparciu o opisaną metodę, zostały zaprezentowane $\mathrm{w}$ tabelach, $\mathrm{w}$ układzie zgodnym $\mathrm{z}$ poszczególnymi „stacjami” gallery walk. W tabelach zamieszczono treści zebrane podczas warsztatów, natomiast część opisowa wprowadza dodatkowe komentarze oraz stanowi próbę uporządkowania wyników.

Grupa zajmująca się zagadnieniem obcokrajowców jako użytkowników zewnętrznych miasta wyróżniła kilka spójnych kategorii miejsc, takich jak: (1) węzły transportowe; (2) szkoły wyższe; (3) miejsca kojarzone $z$ aktywnością zawodową; (4) miejsca kultu religijnego; (5) placówki kulturowe; (6) obiekty usługowe (por. tab. 1). Ponadto w aspekcie przestrzennym podkreślone zostały tendencje do skupiania się (gettoizacji) lub rozpraszania grup cudzoziemców.

Tabela 1. Wyniki dyskusji odnośnie do obcokrajowców

\begin{tabular}{|c|c|}
\hline Miejsca & Zachowania \\
\hline $\begin{array}{l}\text { Lotniska, dworce, urzędy, granice, restauracje etniczne, } \\
\text { Stary Rynek, Cytadela, getta (koncentracja/segregacja), } \\
\text { szkoły wyższe, punkty informacji turystycznej, hotele, } \\
\text { kościoły (miejsca kultu), stadiony, miejsca związane } \\
\text { z przyjmowaniem artystów, urzędy miasta, biura, kor- } \\
\text { poracje, bazary/targi, szkoły językowe }\end{array}$ & $\begin{array}{l}\text { Zachowania tradycyjne, migracje tym- } \\
\text { czasowe, sytuacje konfliktowe, bariery } \\
\text { językowe, tolerancja/brak tolerancji, } \\
\text { komunikacja/nawiązywanie kontaktów, } \\
\text { praca, przestępczość, nielegalny pobyt } \\
\text { i praca, handel, żebractwo, patologie } \\
\text { społeczne, prostytucja, wprowadzanie } \\
\text { nowych religii }\end{array}$ \\
\hline Wkład w życie miasta $(+/-)$ & Inne \\
\hline $\begin{array}{l}\text { Społeczne, kulturowe, gospodarcze, archipelagowość } \\
(-) \text {, gettoizacja, ożywienie, dobre praktyki/przyzwycza- } \\
\text { jenia (np. studenci zagraniczni), nowe wzorce kulturo- } \\
\text { we, przełamywanie stereotypów, kreatywność/innowa- } \\
\text { cyjność, oryginalność, różnorodność, ponadnarodowa } \\
\text { przestrzeń społeczna, wzrost PKB, tańsze usługi (prace } \\
\text { budowlane), wzorotwórczość, autopromowanie własnej } \\
\text { kultury, edukacja w zakresie języka, transfer wiedzy, } \\
\text { wolontariat }\end{array}$ & $\begin{array}{l}\text { Kontrapunkt/dystans/autorefleksja, } \\
\text { uśmiech, dyskusja nad wielokulturo- } \\
\text { wością, inność/dziwność, spotkania } \\
\text { językowe }\end{array}$ \\
\hline
\end{tabular}

Źródło: opracowanie własne na podstawie wyników warsztatów. 
Zjawisko to uzależnione jest od stopnia ich asymilacji przestrzennej, która jest odwrotnie proporcjonalna do tendencji skupiających (im bardziej zasymilowani przestrzennie są obcokrajowcy, tym bardziej rozpraszają się w przestrzeni miasta). Część zachowań wskazywanych jako charakterystyczne dla omawianej grupy, np. wprowadzanie nowej religii, jest bezpośrednio związana z wymienionymi wcześniej miejscami. Pozostałe dotyczą często relacji z innymi użytkownikami miast i obejmują m.in. nawiązywanie kontaktu, sytuacje konfliktowe, tolerancję lub jej brak. Wymienia się również zachowania patologiczne, w tym żebractwo, a nawet działalność o charakterze przestępczym. W ramach dyskusji podkreślono także znaczący wkład obcokrajowców w życie miasta. Już na wstępie zwrócono uwagę, że ma on wpływ pozytywny i negatywny oraz wymiar społeczny, kulturowy i gospodarczy. Uczestnicy warsztatu uznali, że cudzoziemcy mogą ożywiająco oddziaływać na miasto np. poprzez wprowadzanie nowych wzorców kulturowych, przełamywanie stereotypów, kreatywność czy różnorodność. Związany $z$ tą grupą jest też transfer wiedzy, przenoszenie pozytywnych przyzwyczajeń lub dobrych praktyk (przy czym należy pamiętać, że uwaga ta może dotyczyć również przyzwyczajeń lub praktyk negatywnych). W aspekcie ekonomicznym podkreślony został wpływ na wzrost PKB oraz spadek cen usług świadczonych przez obcokrajowców (na przykładzie branży budowlanej).

W ramach dodatkowych kwestii uczestnicy wymienili prowokowanie dyskusji nad wielokulturowością. Ich zdaniem stanowi ona wynik obecności cudzoziemców w przestrzeni miejskiej oraz zainteresowania, które wzbudzają u pozostałych mieszkańców. Dyskusja ta pozwala przyjąć rozmaite punkty widzenia, przez co może inspirować do autorefleksji i wpływać na poglądy mieszkańców miasta.

Drugą $z$ analizowanych $\mathrm{w}$ ramach warsztatów gallery walk grup użytkowników przestrzeni miejskiej byli studenci, którzy według uczestników dyskusji, preferują: (1) miejsca związane $z$ nauką i (2) miejsca związane $z$ rekreacją i wypoczynkiem (por. tab. 2). Wskazywane miejsca miały wyraźny związek z zachowaniami,

Tabela 2. Wyniki dyskusji odnośnie do studentów

\begin{tabular}{ll}
\hline \multicolumn{1}{c}{ Miejsca } & \multicolumn{1}{c}{ Zachowania } \\
\hline $\begin{array}{l}\text { Akademiki, kampusy, puby, kluby, obiekty uczelnia- } \\
\text { ne, publiczne miejsca spotkań (parki, mosty, deptaki, } \\
\text { ławki, pomniki, nadrzecza, plaże), obiekty sportowe, } \\
\text { biblioteki, dyskonty, second handy, bary mleczne, } \\
\text { skłoty }\end{array}$ & $\begin{array}{l}\text { wanie/ruchliwośćć), praca +studia, pomoc } \\
\text { w przestrzeni publicznej, aktywność na } \\
\text { wielu polach, spontaniczność, nieprzewidy- } \\
\text { walność, grupowość, nadużywanie alkoholu } \\
\text { i środków psychoaktywnych, oportunizm }\end{array}$ \\
\hline \multicolumn{1}{c}{ Wkład w życie miasta (+/-) } & \multicolumn{1}{c}{ Inne } \\
\hline $\begin{array}{l}\text { (+): finanse uczelni, finanse miasta, finanse miesz- } \\
\text { kańców, odmłodzenie miasta, witalność/żywotność, }\end{array}$ & Zmienność/niestałość \\
$\begin{array}{l}\text { wielokulturowość, różnorodność, wkład w naukę, } \\
\text { lamanie „nudy miejskiej”, kreowanie (inspirowanie) } \\
\text { nowych miejsc spotkań, wkład w rozwój komunikacji }\end{array}$ & \\
publicznej i rowerowej, tania siła robocza; (-): hałas \\
nocny, nieliczenie się z mieszkańcami, tłok (komuni- \\
kacja miejska), zaśmiecenie miasta
\end{tabular}

Źródło: opracowanie własne na podstawie wyników warsztatów. 
które, zdaniem zgromadzonych na seminarium ekspertów, wiążą się z obowiązkami studenckimi z jednej strony i szeroko rozumianym "luźnym” stylem bycia $z$ drugiej. Zauważono również, że proporcje pomiędzy obowiązkami a rozrywką są często uzależnione od tego, czy dany student podejmuje dodatkowo pracę zawodową. Studenci są ponadto postrzegani jako osoby względnie często zmieniające miejsce zamieszkania, mobilne, spontaniczne i aktywne na wielu polach działalności. Przykładem wskazanych zachowań negatywnych jest nadużywanie alkoholu i środków psychoaktywnych. Większość uczestników zgadzała się z faktem, że wkład studentów w życie miasta jest zdecydowanie zauważalny. Jednocześnie potrafili oni zazwyczaj wskazać zarówno aspekty pozytywne, jak i negatywne tego wpływu. Po stronie plusów wymieniono m.in. aspekt finansowy (oddziaływanie zarówno na budżet uczelni, miasta, jak i mieszkańców), pozytywny wpływ na strukturę demograficzną miasta, ożywienie, witalność, rozwój nauki, promowanie korzystania z komunikacji publicznej i inne. Przykłady zachowań negatywnych wiązały się z uciążliwością dla pozostałych mieszkańców, głównie poprzez: zakłócanie ciszy nocnej, zatłoczenie komunikacji publicznej czy też zaśmiecanie miasta.

Osoby biorące udział $\mathrm{w}$ warsztatach $\mathrm{z}$ obecnością mieszkańców strefy podmiejskiej kojarzyły najczęściej miejsca pracy oraz świadczenia usług wyższego rzędu (por. tab. 3). Są one związane z lokalizacją w dużych miastach centrów handlowych, znaczących węzłów komunikacyjnych oraz placówek opieki zdrowotnej $\mathrm{i}$ instytucji kultury. Zachowania wskazywane przez uczestniczących w dyskusji ekspertów wynikały $z$ realizacji różnego rodzaju potrzeb oraz pracy $\mathrm{w}$ mieście. Duży nacisk położono na kwestie będące konsekwencją konieczności dojazdów do pracy: niedostateczny stopień rozwoju komunikacji publicznej oraz kongestię związaną z korzystaniem z transportu indywidualnego. Żywiołowa dyskusja przebiegała na temat wkładu mieszkańców strefy podmiejskiej w życie miasta. $\mathrm{Z}$ jednej strony podkreślano silne i niemal symbiotyczne powiązania $\mathrm{w}$ ramach aglomeracji miejskich, $z$ drugiej natomiast - wynikające $z$ takiego stanu rzeczy problemy i konflikty. Zauważono, że "strefa podmiejska” odciąża miasto w zakresie realizacji niektórych funkcji, ale jednocześnie jej mieszkańcy nadużywają

Tabela 3. Wyniki dyskusji odnośnie do mieszkańców strefy podmiejskiej

\begin{tabular}{|c|c|}
\hline Miejsca & Zachowania \\
\hline $\begin{array}{l}\text { Hipermarket, miejsce pracy, kultura instytucjonalna/instytu- } \\
\text { cje kultury, nauka (ponadgimnazjalna), tereny rekreacyjne, } \\
\text { miejsca realizacji usług wyższego rzędu, węzły transportowe, } \\
\text { miejsca konsumpcji, Central Business District, służba zdrowia } \\
\text { (wyższego rzędu) }\end{array}$ & $\begin{array}{l}\text { Dojazdy, stanie w korkach, } \\
\text { narzekanie na dostęp do miasta, } \\
\text { zakupy, brak/powierzchowność } \\
\text { kontaktu z miastem, czasochłon- } \\
\text { ne korzystanie z komunikacji }\end{array}$ \\
\hline Wkład w życie miasta $(+/-)$ & Inne \\
\hline $\begin{array}{l}\text { „korzystam z Poznania, nie płacąc tu podatków” (i na odwrót), } \\
\text { odciążenie miasta poprzez przejęcie części funkcji, genero- } \\
\text { wanie ruchu komunikacyjnego, miejsca wywozu śmieci (z } \\
\text { miasta), mniejsza presja rezydencjonalna, aktywizacja dzielnic } \\
\text { peryferyjnych, „zasamochodowienie”, „lokalne” graffiti, nega- } \\
\text { tywny wpływ na środowisko, dodatkowe tereny rekreacyjne }\end{array}$ & $\begin{array}{l}\text { Wnętrze samochodu, poczucie } \\
\text { wykluczenia ze wspólnoty miej- } \\
\text { skiej (zasłużone lub nie), „sypial- } \\
\text { nia miast”, „półurbanizacja” }\end{array}$ \\
\hline
\end{tabular}

Źródło: opracowanie własne na podstawie wyników warsztatów. 
Tabela 4. Wyniki dyskusji odnośnie do turystów

\begin{tabular}{ll}
\hline \multicolumn{1}{c}{ Miejsca } & \multicolumn{1}{c}{ Zachowania } \\
\hline $\begin{array}{l}\text { Zabytki, gastronomia, muzea, galerie, obiekty kultu- } \\
\text { ralne, obiekty targowe i konferencyjne, lokalne targi, } \\
\text { festiwale, parkingi, lotnisko, obiekty sportowe, hotele, }\end{array}$ & $\begin{array}{l}\text { Fotografowanie, zagubienie, dezorien- } \\
\text { tacja, poszukiwanie wiedzy (czytanie } \\
\text { opisów), biesiadowanie, clubbing, } \\
\text { czytanie planów/map, zwiedzanie (także } \\
\text { grupowe), zagadywanie miejscowych }\end{array}$ \\
\hline \multicolumn{1}{c}{ Wkład w życie miasta (+/-) } & \multicolumn{1}{c}{ Inne } \\
\hline $\begin{array}{l}\text { Przeciążenie infrastruktury, wzbogacenie budżetu } \\
\text { miasta i firm, rozwój usług, kontakt międzykulturo- }\end{array}$ & $\begin{array}{l}\text { Punktowe poznawanie miasta, fascynacja } \\
\text { innościa, weryfikacja stereotypów (mo- } \\
\text { tyw, hałas i tłok, kosmopolityzacja (języki, kuchnia), } \\
\begin{array}{l}\text { inwestycje, szyldy, humor, miejsca pracy, podnoszenie Józef Tkaczuk” } \\
\text { kwalifikacji językowych, tolerancja, otwartość }\end{array}\end{array}$ \\
\hline
\end{tabular}

Źródło: opracowanie własne na podstawie wyników warsztatów.

infrastruktury, która nie jest finansowana z ich podatków. Zmniejszają oni presję rezydencjonalną na wolne tereny $\mathrm{w}$ mieście, jednocześnie generując duży ruch komunikacyjny, co jeden z uczestników warsztatu nazwał „zasamochodowieniem miasta". W dodatkowych komentarzach podkreślono, że strefa podmiejska jest często „sypialnią miasta”, a jej mieszkańcy czują się wykluczeni z miejskiej wspólnoty.

Kolejną ujętą $\mathrm{w}$ analizie grupą byli turyści. Uczestnicy warsztatów kojarzyli z turystami takie miejsca, jak: (1) zabytki i atrakcje turystyczne; (2) obiekty usługowe, w tym baza noclegowo-gastronomiczna; (3) obiekty targowe i konferencyjne; (4) obiekty sportowe (por. tab. 4). W odniesieniu do dużych wydarzeń kulturalnych wskazano również na miejsca organizacji festiwali, koncertów itp. Pisząc o wymienianych zachowaniach, można zauważyć, że cechowały się one odmiennością $\mathrm{w}$ stosunku do poprzednich grup, która wynika prawdopodobnie z krótszego pobytu i mniejszej znajomości odwiedzanego miasta. Za charakterystyczne dla tej grupy uznano więc m.in.: zagubienie, poszukiwanie wiedzy na mapach i w przewodnikach, zagadywanie miejscowych w poszukiwaniu pomocy. Wymienione zostały też takie aktywności, jak: fotografowanie, biesiadowanie, odwiedzanie klubów nocnych i zwiedzanie (samodzielnie lub w grupie). Pozytywny wkład turystów w życie miasta zauważono głównie pod względem ekonomicznym - w formie zysków dla miasta, przedsiębiorców i mieszkańców, co jest szczególnie efektem rozwoju sektora usługowego. Zdaniem uczestników warsztatu, turyści wnoszą do miasta również otwartość, tolerancję, zapewniają kontakt międzykulturowy i nadają miastu kosmopolityczny charakter. Zauważono jednak też negatywny wpływ w postaci przeciążenia miejskiej infrastruktury, nadmiernego hałasu i zatłoczenia.

Dodatkowe kwestie poruszone w odniesieniu do turystów wskazywały m.in. na punktowy charakter poznawania miasta. Jest on związany z odwiedzaniem przede wszystkim najbardziej popularnych atrakcji turystycznych, często wyznaczonych jeszcze przed przyjazdem do miasta. Kolejnym zaobserwowanym zjawiskiem była fascynacja innością we wzajemnych kontaktach mieszkańców miasta oraz turystów. 


\section{Podsumowanie}

Przebieg i wyniki dyskusji, pozornie oczywiste, dają jednak odpowiedź na pytanie o to, czy użytkowników zewnętrznych polskich miast należy uznawać za istotny podmiot życia miejskiego, czy raczej powinniśmy skupić się na mieszkańcach jako głównych jego aktorach. Oba poglądy pojawiały się w dyskusjach uczestników warsztatów, których wyniki świadczą o tym, że znaczenie city users nie może być pomijane, a w niektórych aspektach jest wręcz dominujące. Sam fakt dostrzegania licznych przykładów pozytywnego i negatywnego wkładu użytkowników zewnętrznych w życie miasta świadczy o roli, jaką mogą oni w nim pełnić. Tezy o istotności grup użytkowników zewnętrznych broni też fakt, że w trakcie dyskusji identyfikowano miejsca kojarzone przede wszystkim właśnie $z$ tym typem użytkownika. Świadczy to o istnieniu w mieście takich struktur przestrzennych, z których korzystają, a co więcej - które są kształtowane przez użytkowników zewnętrznych.

Wpływ użytkowników zewnętrznych na miasto przejawia się w wielu aspektach jego funkcjonowania, w tym: społecznym, kulturowym i ekonomicznym. Aspekt kulturowy dyskutowany był najszerzej w odniesieniu do cudzoziemców. Ich obecność daje mieszkańcom możliwość bezpośredniego poznawania obcych kultur lub religii, co wpływa na wzrost różnorodności środowiska miejskiego oraz poziomu tolerancji mieszkańców, ale może być również zarzewiem konfliktów. Negatywne zjawiska może też wywoływać obecność pozostałych grup city users, których interesy są częściowo sprzeczne z interesami rdzennych mieszkańców miast. Z tego powodu różnego rodzaju sytuacje konfliktowe wskazywane były w odniesieniu do każdej z kategorii użytkowników zewnętrznych. Za pozytywne zjawisko, w aspekcie społecznym, uznano natomiast zwiększanie społecznego zróżnicowania miast poprzez napływ użytkowników zewnętrznych. Jego efektem ma być między innymi wzrost kreatywności, poprawa jakości i zróżnicowania kapitału ludzkiego, nowe wzorce zachowań. Mierzalne skutki obecności wymienionych grup skupiają się w ramach wymiaru ekonomicznego. Związany jest on ze stymulowaniem lokalnej gospodarki, wzrostem konkurencyjności na rynku wewnętrznym, dodatkowymi dochodami do budżetu miasta oraz podmiotów prywatnych. W trakcie dyskusji podnoszono również kwestie odnoszące się do przestrzeni i fizycznego rozmieszczenia poszczególnych grup na terenie miasta. Zauważono m.in. przeciwstawne skłonności cudzoziemców do skupiania się lub rozpraszania (w zależności od stopnia ich asymilacji), wysoką mobilność studentów, wyspowe nagromadzenia turystów czy dobowe wahania obecności mieszkańców strefy podmiejskiej.

Krótki przegląd wyników warsztatu pozwala zauważyć, że każda z grup użytkowników zewnętrznych w mniejszym lub większym stopniu zawłaszcza określone miejsca, jest charakteryzowana ze względu na swój sposób zachowania oraz ma swój wkład w życie miasta. Należy podkreślić żywiołowość, z jaką toczyła się debata na temat mieszkańców strefy podmiejskiej. Grupa ta wywołała największe kontrowersje, a w trakcie dyskusji pojawiały się głosy skrajnie przeciwne. Mieszkańcy suburbiów byli przez uczestników warsztatu uznawani za nadmier- 
nie wykorzystujących infrastrukturę, generujących niepotrzebny ruch i korkujących miasto. Podnoszono dodatkowy argument, że generowane przez nich problemy są rozwiązywane z podatków mieszkańców. Zdarzały się jednak również głosy podkreślające fakt, że grupa ta zapewnia siłę roboczą dla miejskich przedsiębiorstw, udostępnia mieszkańcom miasta własną infrastrukturę, funkcjonalnie odciąża miasto itp. Wątki te są szczególnie interesujące w kontekście szerszej dyskusji o przestrzennym rozlewaniu się miast na strefę podmiejską, o kurczeniu się (demograficznym) miast $\mathrm{w}$ swych granicach administracyjnych czy o ich zrównoważonym rozwoju.

\title{
Literatura
}

Fasse B., Kolodner J. 2000. Evaluating Classroom Practices Using Qualitative Research Methods: Defining and Refining the Process. [W:] B. Fishman, S. O'Connor-Divelbiss (red.), Fourth International Conference of the Learning Sciences. Erlbaum, Mahwah, s. 193-198.

Francek M. 2006. Promoting Discussion in the Science Classroom Using Gallery Walks. Journal of College Science Teaching, 36(1): 27-31.

Holbrook J., Kolodner J. 2000. Scaffolding the Development of an Inquiry-Based (Science) Clasroom. [W:] B. Fishman, S. O'Connor-Divelbiss (red.), Fourth International Conference of the Learning Sciences. Erlbaum, Mahwah, s. 221-227.

Judd D. 2003. Visitors and the Spatial Ecology of the City. [W:] L. Hoffman, S. Fainstein, D. Judd (red.), Cities and Visitors. Regulating People, Markets and City Space. Blackwell Publishing, Oxford-Malden, s. 23-38.

Kolodner J. 2002. Facilitating the Learning of Design Practices: Lessons Learned from an Inquiry into Science Education. Journal of Industrial Teacher Education, 39(3).

Martinotti G. 1996. Four Populations: Human Settlements and Social Morphology in Contemporary Metropolis. European Review, 4(1): 1-21.

Nuvolati G. 2003. Resident and Non-resident Populations: Quality of Life, Moblity and Time Policies. The Journal of Regional Analysis and Policy, 33(2): 67-83.

\section{City Users in Poland. Summary of the Gallery Walk Workshop}

\begin{abstract}
This paper is a result of the gallery walk workshop conducted in a group of specialists from various branches of science connected with the urban research, during the seminary summarizing the EBEH Project "Guests in a City - a City in relation to visitors - analysis of socio-spatial city structures in context of the City Users theory". The gallery walk method was used as a tool to stimulate the discussion on four groups of city users in polish cities: students, tourists, foreigners and suburbs inhabitants. The results of discussion were compared with some main assumptions of the City Users theory. This approach helped authors to answer their main question: Are city users in polish cities as important as they are in described cases from Western Europe?
\end{abstract}

Key words: gallery walk, city users, city structure 